\title{
Production and Optimization of Endoglucanase by Aspergillus sp., Trichoderma sp. and Penicillium sp.
}

\author{
Kirit B. Patel ${ }^{1}$, S.S. Patel ${ }^{2}$, B.K. Patel ${ }^{1}$, H.C. Chauhan ${ }^{2}$, Manish Rajgor ${ }^{2}$, J.K. Kala ${ }^{2}$, \\ M.A. Patel ${ }^{2}$, M.G. Patel ${ }^{2}$, A.C. Patel ${ }^{2}$, M.D. Shrimali ${ }^{2}$, A.N. Modi' ${ }^{2}$ and B.S. Chandel ${ }^{2}$ \\ ${ }^{1}$ Ashok and Rita Patel Institute of Study and Research in Biotechnology and Allied Sciences, \\ New Vallabh Vidyanagar- 388121, Sardar Patel University V.V.Nagar-388120, Gujarat, India \\ ${ }^{2}$ Department of Animal Biotechnology and Microbiology, Veterinary College, S.D.A.U., \\ Sardarkrushinagar-385506, Gujarat, India \\ *Corresponding author
}

\author{
A B S T R A C T
}

Keywords

Submerged fermentation, Endo-ß-glucanase, Optimization.

Article Info

Accepted:

12 March 2017

Available Online:

10 April 2017
Endoglucanase is one of the most important industrial enzymes. In the present study, three different fungi Aspergillus sp., Trichoderma sp. and Penicillium sp. were isolation for endoglucanase production from soil samples on PDA plate. All three fungus processed by submerged fermentation and solid state fermentation for its enzymatic activity. Aspergillus $s p$., showed highest enzymatic activity in both type of fermentation. In solid state fermentation using sawdust, corncob and wheat bran substrate, all three fungus give highest enzyme activity in corncob substrate as compared to sawdust and wheat bran substrate. The optimization of endoglucanase activity of Aspergillus sp., Trichoderma sp. and Penicillium $s p$. with different parameter like $\mathrm{pH}$, temperature, carbon source, nitrogen source, CMC concentration and incubation period. Aspergillus sp. give maximum endo- $\beta-$ glucanase activity at $\mathrm{pH} 3,28^{\circ} \mathrm{C}$ temperature, corn starch as a carbon source, sodium nitrate as a nitrogen source, $1.5 \% \mathrm{CMC}$ concentration and 6 days incubation period.

\section{Introduction}

Endoglucanase is one of the most important industrial enzymes. Approximately $75 \%$ of industrial enzyme is used for hydrolysis and depolymerization of complex natural substance (Kirk et al., 2002). Microbial enzymes have two enormous advantages of being able to be produced in large quantities by established fermentation technique. Also, it is infinitely easier to improve the productivity of a microbial system compared with plant or animal and microbial enzyme has various applications in different sectors (Periasamy et al., 2013). Successful utilization of cellulosic materials as renewable carbon sources is dependent on the development of economically feasible process technologies for cellulose production. A cellulosic enzyme system consists of three major components: endo- $\beta$-glucanase, exo- $\beta$ glucanase and $\beta$-glucosidase (Bhat, 2000). Most fungal cellulases have a two-domain structure, with one catalytic domain and one cellulose binding domain that are connected by a flexible linker. This structure is adaption for working on an insoluble substrate, and it allows the enzyme to diffuse two- 
dimensionally on a surface in a caterpillar way. However, there are also cellulases (mostly endoglucanases) that lack cellulose binding domains. These enzymes might have a swelling function (Saddler et al., 1995). Most cellulases studied have similar $\mathrm{pH}$ optima, solubility and amino acid composition (Schulein, 1997). Thermal stability and exact substrate specificity may vary. This study focused on isolation of a high endoglucanase producing fungi from soil samples and improvement of enzyme productivity by supplementation with nitrogen and carbon sources, $\mathrm{pH}$ and optimization.

\section{Materials and Methods}

\section{Isolation and identification of fungi}

Collect soil samples in sterile bag and diluted in distilled water. Diluted soil samples $\left(10^{-4}\right)$ were spread on PDA plates and incubated at $28^{\circ} \mathrm{C}$ for 5 days.PDA plates were observed for the morphology of fungi (Table 1). Alactophenol cotton blue stain was used for the identification of fungi (Aneja, 2001).Cultivated fungus of PDA plate was grown on CMC agar plate and Incubated at $28^{\circ} \mathrm{C}$ for 5 days was stained with congored (1\%) for $15 \mathrm{~min}$ and wash with $1 \mathrm{M} \mathrm{NaCl}$ according to the method of cellulolytic activity of fungus (Hankin and Anagnostaksis, 1975).Pure culture of fungi (Aspergillus sp., Trichoderma sp. and Penicillium sp.) was preserve on PDA slant at $4^{\circ} \mathrm{C}$ (Fig. 3).

\section{Growth condition and enzyme production}

\section{Submerged fermentation}

Take the spore suspension into CMC broth in flask and incubated in shaker at $120 \mathrm{rpm}$, $28^{\circ} \mathrm{C}$ for 5 days. After incubation filter it with muslin cloth, collect the filtrate and centrifuge at $10,000 \mathrm{rpm}, 4^{\circ} \mathrm{C}$ for $15 \mathrm{~min}$. Collect the supernatant and used as crude enzyme.

\section{Solid state fermentation}

Three substrates (saw dust, corn cob, and wheat bran) were collected from the local market. Substrates were crushed with the help of grinder, sieve and autoclave it at $121^{\circ} \mathrm{C}$ for $15 \mathrm{~min}$. For fermentation 10-15 $\mathrm{ml} 5$ days old broth culture of fungi mix with saw dust, corn cob, and wheat bran substrates in different flask and incubate at $28^{\circ} \mathrm{C}$ for 5 days in static condition. After incubation add 10-15 ml of phosphate buffer $(0.1 \mathrm{M}, \mathrm{pH} 5)$ in each flask and mix it properly. Then filter through muslin cloth. Collect the filtrate and centrifuge at $10,000 \mathrm{rpm}, 4^{\circ} \mathrm{C}$ for $15 \mathrm{~min}$. collect the supernatant and used as the crude enzyme preparation.

\section{Enzyme assay}

Enzyme assay was done by DNS or DNSA method (3,5-Dinitrosalicylic acid)(miller 1959).A reaction mixture composed of $1 \mathrm{ml}$ of crude enzyme, $0.5 \mathrm{ml} \mathrm{CMC} \mathrm{(0.5 \% ),} 0.5 \mathrm{ml}$ citrate buffer $(0.05 \mathrm{M})$ was incubated at $40^{\circ} \mathrm{C}$ in water bath for $15 \mathrm{~min}$. The reaction was terminated by adding $3 \mathrm{ml}$,5-Dinitrosalicylic acid (Sigma Aldrich, USA) and optical densities were measured at $540 \mathrm{~nm}$ by using spectrophotometer against a blank containing all the reagents. Results were interpreted in term of enzyme activity in which one unit (U) of enzyme activity was defined as the amount of enzyme that liberates $1 \mu \mathrm{mol}$ glucose per minute under the above condition.

Enzyme Activity $=\quad$ Amount of sugar released (Conc)

Mol.weight of glucosex Vol. of enzyme (ml) $\times$ Incubation time (min) 
Factor affecting endoglucanase production

The effect of carbon and nitrogen sources on growth and endo-ß-glucanase production was investigated by inoculating spore suspension in CMC fermentation medium supplemented with different nitrogen sources(peptone, beef extract, ammonium nitrate, sodium nitrate) and carbon sources(glucose, sucrose, mannitol, corn starch) and incubate for 5 days. After incubation, endoglucanase activity analyze by enzyme assayed. To study the effect of $\mathrm{pH}(3,5,7,9)$, Temperature $\left(28^{\circ} \mathrm{C}\right.$, $37^{\circ} \mathrm{C}, 50^{\circ} \mathrm{C}$ ), Incubation Period(up to 8 days)and CMC concentration (1.0\%, $1.5 \%, 2.0 \%)$ was prepared and inoculated. Examine the various factor effects on microbial growth and enzyme activity.

\section{Results and Discussion}

\section{Isolation and identification of fungi}

Three fungus Aspergillus sp., Trichoderma $s p$. and Penicillium sp. were isolated from the soil sample and identified using lactophenol cotton blue staining method (Fig. 1). All three fungi produce a zone of hydrolysis (Fig. 2) around the fungal colonies when flooded with congo red stain. Aneja (2001) also observes similar result. A zone of hydrolysis around the fungal colonies indicates all three fungi produce endoglucanase enzyme. These methods are rapid and efficient for bacteria and fungi (Ramesh et al., 2008).

\section{Growth condition and enzyme production}

\section{Submerged fermentation}

In Submerged fermentation Aspergillus sp. $(0.124$ Units $/ \mathrm{ml})$ gives highest enzyme activity followed by Trichoderma sp. $(0.118$ Units $/ \mathrm{ml})$ and Penicillium sp. $\quad(0.118$ Units/ml). Penicillium $s p$. gives the highest specific activity $(1.9 \mu \mathrm{mol} / \mathrm{ml} / \mathrm{mg}$ of protein) compared to Aspergillus sp. $(1.0 \mu \mathrm{mol} / \mathrm{ml} / \mathrm{mg}$ of protein) and Trichoderma sp. (1.84 $\mu \mathrm{mol} / \mathrm{ml} / \mathrm{mg}$ of protein) (Table 2). Aspergillus niger produce significant cellulase activity in media containing cellulose and CMC as sole carbon sources in submerged fermentation (Gautam et al., 2010).

\section{Solid state fermentation}

All three fungus gives highest enzyme activity in corn cob followed by wheat bran and saw dust substrate (Table 3). In contrast to present finding (Abo-state et al., 2010) shown highest cellulases were produced using agriculture wastes in the order Wheat straw> Wheat bran> Rice straw> Corn cob. In present study highest enzyme activity observe in solid state fermentation as compare to submerged fermentation. Present finding was in agreement with Gautam et al., (2011) which observe solid state fermentation gives higher enzyme activity and the lowest chances of bacterial contamination, so solid state fermentation is better than submerged fermentation.

\section{Optimization of endoglucanase production}

\section{Effect of pH}

For Aspergillus sp. and Penicillium sp. maximum enzyme activity $(0.325$ $\mu \mathrm{mol} / \mathrm{ml} / \mathrm{min}$ and $0.251 \mu \mathrm{mol} / \mathrm{ml} / \mathrm{min}$ respectively) at $\mathrm{pH} 3$ and Trichoderma $s p$. maximum enzyme activity $(0.116 \mu \mathrm{mol} / \mathrm{ml} / \mathrm{min})$ at $\mathrm{pH} 7$ (Table 4$)$, earlier studies reported maximum enzyme activityof Aspergillus nigerand Penicillium chrysogenum at $5 \mathrm{pH}$ (Jayant et al., 2011), Trichoderma sp. at $6.5 \mathrm{pH}$ (Gautam et al., 2011) and Aspergillus niger at $4.0-4.5 \mathrm{pH}$ (Acharya et al., 2008).

\section{Effect of temperature}

Aspergillus sp. showed maximum enzyme activity of endoglucanase $(0.055 \mu \mathrm{mol} / \mathrm{ml} / \mathrm{min})$ at $28^{\circ} \mathrm{C}$ and above $28^{\circ} \mathrm{C}$ 
decrease its enzyme activity. However, Trichoderma and Penicillium sp give maximum enzyme activity $(0.055 \mu \mathrm{mol} / \mathrm{ml} / \mathrm{min}$ and $0.096 \mu \mathrm{mol} / \mathrm{ml} / \mathrm{min}$ respectively) at $50^{\circ} \mathrm{C}$ (Table 5).

Similar to present finding Gautamet al.(2011) observed Trichodermasp. give maximum enzyme activity of endoglucanase at $45^{\circ} \mathrm{C}$ and Acharya et al., (2008) found Aspergillus niger give maximum activity at $28^{\circ} \mathrm{C}$.

\section{Effect of incubation period}

The cellulase activity of endoglucanase was measured at regular intervals. However, the maximum activity was obtained on $5^{\text {th }}$ and $6^{\text {th }}$ days of incubation. Aspergillus sp. gives maximum enzyme activity $(0.140 \mu \mathrm{mol} / \mathrm{ml} / \mathrm{min})$ on $6^{\text {th }}$ day. Trichoderma and Penicillium sp. gives maximum enzyme activity $\quad(0.111 \quad \mu \mathrm{mol} / \mathrm{ml} / \mathrm{min} \quad$ and $0.092 \mu \mathrm{mol} / \mathrm{ml} / \mathrm{min}$ respectively) on $5^{\text {th }}$ day (Table 6).

Table.1 Colony characteristic of fungi

\begin{tabular}{|c|c|c|c|c|}
\hline Species & Colour & Size & Margin & Appearance \\
\hline Aspergillus & Black & Big & Round & Powdery \\
\hline Trichoderma & Greenish blue & Medium & Spread & Cottony \\
\hline Penicillium & Green & Big & Round & Powdery \\
\hline
\end{tabular}

Table.2 Enzyme activity in $\mathrm{SmF}$

\begin{tabular}{|c|c|c|}
\hline Species & $\begin{array}{c}\text { Enzyme Activity } \\
(\boldsymbol{\mu m o l} / \mathbf{m l} / \mathbf{m i n})\end{array}$ & $\begin{array}{c}\text { Specific activity } \\
(\boldsymbol{\mu m o l} / \mathbf{m l} / \mathbf{m g} \text { of } \text { protein) }\end{array}$ \\
\hline Aspergillus & 0.124 & 1.0 \\
\hline Trichoderma & 0.118 & 1.84 \\
\hline Penicillum & 0.103 & 1.9 \\
\hline
\end{tabular}

Table.3 Enzyme activity of SSF

\begin{tabular}{|c|c|c|c|}
\hline \multirow{2}{*}{ Species } & \multicolumn{3}{|c|}{ Enzyme activity $(\boldsymbol{\mu m o l} / \mathbf{m l} / \mathbf{m i n})$} \\
\cline { 2 - 4 } & \multicolumn{3}{|c|}{ Substrates } \\
\cline { 2 - 4 } & Saw dust & Corn cob & Wheat bran \\
\hline Aspergillus & 0.066 & 1.42 & 0.290 \\
\hline Trichoderma & 0.067 & 0.859 & 0.301 \\
\hline Penicillum & 0.087 & 1.155 & 0.307 \\
\hline
\end{tabular}

Table.4 Effect of $\mathrm{pH}$

\begin{tabular}{|c|c|c|c|c|}
\hline \multirow[t]{2}{*}{ Species } & \multicolumn{4}{|c|}{ Enzyme activity( $\mu \mathrm{mol} / \mathrm{ml} / \mathrm{min})$} \\
\hline & pH 3 & pH 5 & pH 7 & pH 9 \\
\hline Aspergillus & 0.325 & 0.005 & 0.029 & 0.037 \\
\hline Trichoderma & 0.098 & 0.029 & 0.116 & 0.037 \\
\hline Penicillum & 0.251 & 0.061 & 0.048 & 0.011 \\
\hline
\end{tabular}


Table.5 Effect of temperature

\begin{tabular}{|c|c|c|c|}
\hline \multirow{2}{*}{ Species } & \multicolumn{3}{|c|}{ Enzyme activity( $\boldsymbol{\mu m o l} / \mathbf{m l} / \mathbf{m i n})$} \\
\cline { 2 - 4 } & $\mathbf{2 8 ^ { \circ } \mathbf { C }}$ & $\mathbf{3 7 ^ { \circ }} \mathbf{C}$ & $\mathbf{5 0}^{\circ} \mathbf{C}$ \\
\hline Aspergillus & 0.055 & 0.029 & 0.024 \\
\hline Trichoderma & 0.037 & 0.038 & 0.055 \\
\hline Penicillium & 0.029 & 0.092 & 0.096 \\
\hline
\end{tabular}

Table.6 Effect of incubation period

\begin{tabular}{|c|c|c|c|c|c|c|c|}
\hline \multirow[t]{3}{*}{ Species } & \multicolumn{7}{|c|}{ Enzyme activity ( $\mu \mathrm{mol} / \mathrm{ml} / \mathrm{min})$} \\
\hline & \multicolumn{7}{|c|}{ Days } \\
\hline & 2 & 3 & 4 & 5 & 6 & 7 & 8 \\
\hline Aspergillus & 0.005 & 0.029 & 0.048 & 0.124 & 0.140 & 0.111 & 0.116 \\
\hline Trichoderma & 0.011 & 0.042 & 0.061 & 0.111 & 0.092 & 0.087 & 0.085 \\
\hline Penicillium & 0.005 & 0.029 & 0.037 & 0.092 & 0.087 & 0.074 & 0.079 \\
\hline
\end{tabular}

Table.7 Effect of carbon sources

\begin{tabular}{|c|c|c|c|c|}
\hline \multirow{2}{*}{ Species } & \multicolumn{4}{|c|}{ Enzyme activity $(\boldsymbol{\mu m o l} / \mathbf{m l} / \mathbf{m i n})$} \\
\cline { 2 - 5 } & Glucose & Sucrose & Mannitol & Corn starch \\
\hline Aspergillus & 0.029 & 0.037 & 0.024 & 0.066 \\
\hline Trichoderma & 0.011 & 0.037 & 0.024 & 0.074 \\
\hline Penicillium & 0.010 & 0.005 & 0.055 & 0.048 \\
\hline
\end{tabular}

Table.8 Effect of nitrogen sources

\begin{tabular}{|c|c|c|c|c|}
\hline \multirow{2}{*}{ Species } & \multicolumn{4}{|c|}{ Enzyme activity( $\mu$ mol/ml/min) } \\
\cline { 2 - 5 } & $\begin{array}{c}\text { Ammonium } \\
\text { Nitrate }\end{array}$ & Peptone & $\begin{array}{c}\text { Beef } \\
\text { extract }\end{array}$ & $\begin{array}{c}\text { Sodium } \\
\text { nitrate }\end{array}$ \\
\hline Aspergillus & 0.005 & 0.048 & 0.010 & 0.079 \\
\hline Trichoderma & 0.018 & 0.055 & 0.037 & 0.074 \\
\hline Penicillium & 0.111 & 0.036 & 0.066 & 0.042 \\
\hline
\end{tabular}

Table.9 Effect of concentration of CMC

\begin{tabular}{|c|c|c|c|}
\hline \multirow{2}{*}{ Species } & \multicolumn{3}{|c|}{ Enzyme activity $(\boldsymbol{\mu m o l} / \mathbf{m l} / \mathbf{m i n})$} \\
\cline { 2 - 4 } & $\mathbf{1 . 0 \%}$ & $\mathbf{1 . 5 \%}$ & $\mathbf{2 . 0 \%}$ \\
\hline Aspergillus & 0.122 & 0.153 & 0.129 \\
\hline Trichoderma & 0.140 & 0.185 & 0.370 \\
\hline Penicillium & 0.135 & 0.214 & 0.338 \\
\hline
\end{tabular}



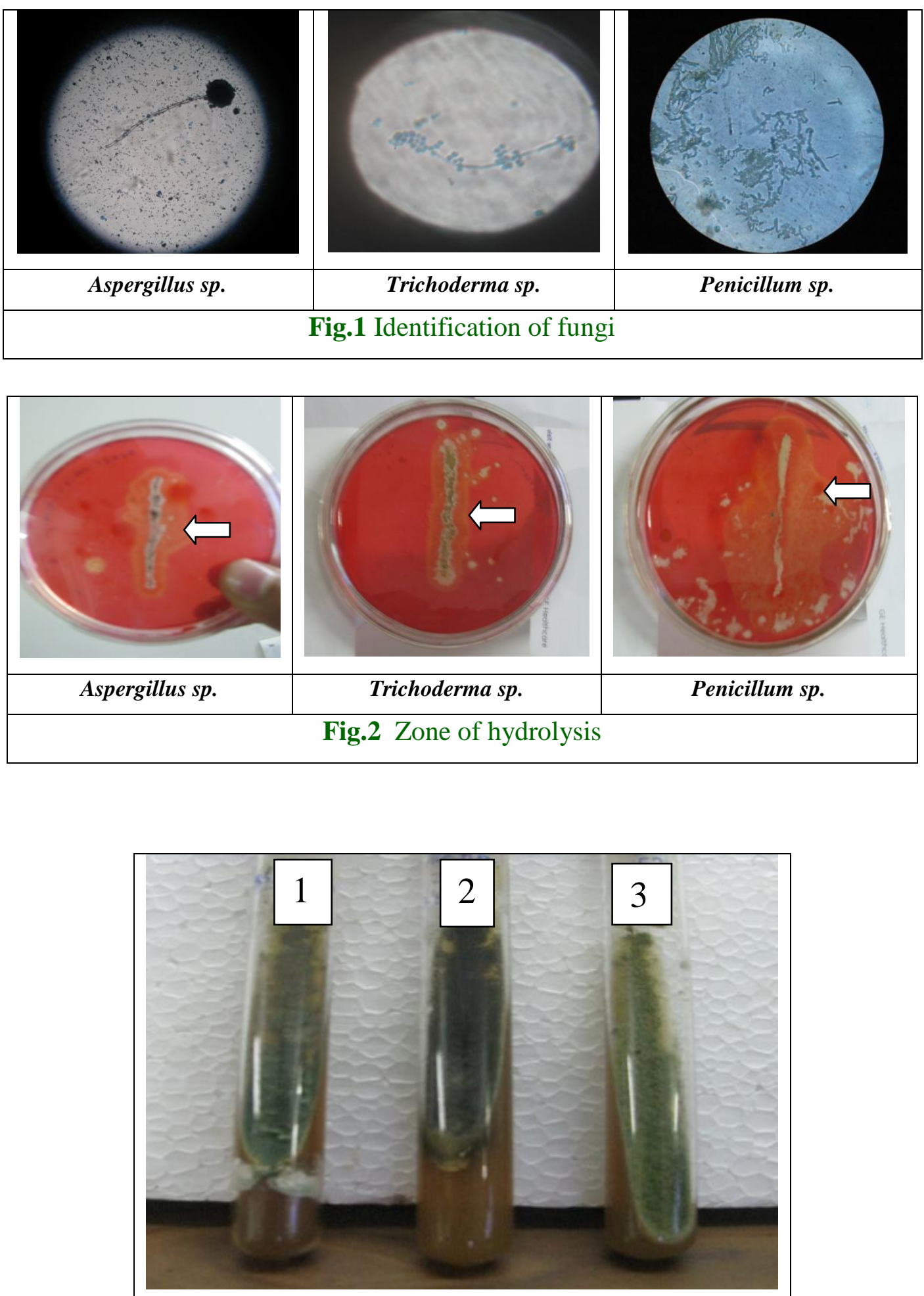

1. Trichoderma sp.,2. Aspergillus sp., 3. Penicillum sp.

Fig.3 Pure culture of fungi(PDA slant) 


\section{Effect of carbon sources}

Aspergillus and Trichoderma sp. gives maximum enzyme activity of endoglucanase $(0.066 \mu \mathrm{mol} / \mathrm{ml} / \mathrm{min}$ and $0.074 \mu \mathrm{mol} / \mathrm{ml} / \mathrm{min}$ respectively) in corn starch and Penicillium sp. gives maximum enzyme activity $(0.055 \mu \mathrm{mol} / \mathrm{ml} / \mathrm{min})$ in mannitol (Table 7$)$. Gautam et al., (2011) observed that Trichoderma sp. gives maximum enzyme activity in sucrose as a carbon sources.

\section{Effect of nitrogen sources}

Aspergillus and Trichoderma sp. gives maximum enzyme activity of endoglucanase $(0.079 \mu \mathrm{mol} / \mathrm{ml} / \mathrm{min}$ and $0.074 \mu \mathrm{mol} / \mathrm{ml} / \mathrm{min}$ respectively) in sodium nitrate compared to other nitrogen sources. While Penicillium sp. gives maximum enzyme activity of endoglucanase $(0.111 \mu \mathrm{mol} / \mathrm{ml} / \mathrm{min})$ in ammonium nitrate (Table 8 ). In contrast to present finding peptone and yeast extract $(1.0 \%(\mathrm{w} / \mathrm{v})$ was best nitrogen sources for the production of endo- $\beta$-glucanase by $A$. niger and Trichoderma sp. (Gautam et al., 2011).

\section{Effect of concentration of CMC (\%)}

Aspergillus sp. gives maximum enzyme activity $(0.153 \mu \mathrm{mol} / \mathrm{ml} / \mathrm{min})$ at $1.5 \% \mathrm{CMC}$ concentration. Trichoderma and Penicillium $s p$. gives the maximum enzyme activity $(0.370 \mu \mathrm{mol} / \mathrm{ml} / \mathrm{min}$ and $0.338 \mu \mathrm{mol} / \mathrm{ml} / \mathrm{min}$ respectively) at $2 \% \mathrm{CMC}$ concentration (Table 9). Jahangeer et al., (2005) observed maximum enzyme activity of endoglucanase by Trichoderma $s p$. at $1 \% \mathrm{CMC}$ concentration and Gautam et al., (2011) observed maximum enzyme activity of Aspergillus niger at $1.0 \%$ CMC.

In conclusion, in submerged fermentation, the optimum parameter namely, temp, $\mathrm{pH}$, incubation period for Aspergillus sp. $\left(28^{\circ} \mathrm{C}\right.$, $\mathrm{pH}-3$ and 6 days), Trichoderma $s p .\left(50^{\circ} \mathrm{C}\right.$,
pH-7 and 5 days) and Penicillium $s p .\left(50^{\circ} \mathrm{C}\right.$, pH-3 and 5 days) were observed. In solid state fermentation, corn cob is the best substrate for endo-ß-glucanase production compared to wheat bran and saw dust. Aspergillus sp. gives the highest enzyme activity in solid state fermentation as well as submerged fermentation compared to Trichoderma $s p$. and Penicillium sp. higher activity was observed in solid state fermentation compared to submerged fermentation. So, solid state fermentation is better than submerged fermentation.

\section{References}

Abo-State, M.A.M., Hammad, A.I., Swelim, M., Gannam, R.B. 2010. Enhanced Production of Cellulase(S) By Aspergillus sp. Isolated From Agriculture Wastes by Solid State Fermentation. American-Eurasian J. Agric. Environ. Sci., 8(4): 402-410.

Acharya, P.B., Acharya, D.K., Modi, H.A. 2008. Optimization for cellulase production by Aspergillus nigerusing saw dust as substrate. Afr. J. Biotechnol., 7(22): 4147-4152.

Aneja, K.R. 2001. Experiments in Microbiology, Plant pathology and Biotechnology, Newage Int. Publishers, (4): 157-162.

Bhat, M.K. 2000. Cellulases and related enzymes in biotechnology. Biotech. $A d v ., 18(5)$ : 355-383.

Gautam, S.P., Bundela, P.S., Pandey, A.K., Khan, J., Awasthi, M.K., Sarsaiya, S. 2010. Optimization of the medium for the production of cellulase by the Trichoderma virideusing submerged fermentation. Int. J. Environ. Sci., 1(4): 656-665.

Gautam, S.P., Bundela, P.S., Pandey, A.K., Khan, J., Awasthi, M.K., Sarsaiya, S. 2011. Optimization for the Production of Cellulase Enzyme from Municipal 
Solid Waste Residue by Two Novel Cellulolytic Fungi. Biotechnol. Res. Int., 8-16.

Hankin, L., Anagnostaksis, L. 1975. The use of solid media for detection of enzyme production by fungi, Mycologia, 47: 597-607.

Jahangeer, S., Khan, N., Jahangeer, S., Muhammad, S., Shahzad, S., Ahmad, A., Khan, S. 2005. Screening and characterization of fungal cellulases isolated from the native environmental sources. Pak. J. Bot., 37(3): 739-748.

Jayant, M., Rashmi, J., Shailendra, M., Deepesh, Y. 2011. Production of cellulase by different co-culture of Aspergillus nigerand Penicillium chrysogenum from waste paper, cotton waste and baggase. Yeast Fungal Res. J., 2(2): 24-27.
Kirk, O., Borchert, T.V., Fuglsang, C.C. 2002. Industrial enzyme application. Curr. Apin. Biotechnol., 13: 345-351.

Periasamy, A., Subash, C.B., Gopinath, A.C., Bidur Prasad, C. 2013. Microbial Enzymes and Their Applications in Industries and Medicine. BioMed. Res. Int., Article ID 204014, 2 pages.

Ramesh, C., Salwan, R., Dhar, H., Dutt, S., Gulati, A. 2008. A Rapid and Easy Method for the Detection of Microbial Cellulases on Agar Plates Using Gram's Iodine. Curr. Microbiol., 57(5): 503-507.

Saddler, J.N., Penner, M.H. 1995. Enzymatic Degradation of Insoluble Carbohydrates, American Chemical Society, Washington: 142-161.

Schulein, M. 1997. Enzymatic properties of cellulases from Humicola insolens. J. Biotechnol., 57(1-3): 71-81.

\section{How to cite this article:}

Kirit B. Patel, S.S. Patel, B.K. Patel, H.C. Chauhan, Manish Rajgor, J.K. Kala, M.A. Patel, M.G. Patel, A.C. Patel, M.D. Shrimali, A.N. Modi and Chandel, B.S. 2017. Production and Optimization of Endoglucanase by Aspergillus sp., Trichoderma sp. and Penicillium sp. Int.J.Curr.Microbiol.App.Sci. 6(4): 1318-1325. doi: https://doi.org/10.20546/ijcmas.2017.604.161 